\title{
Huguenot resistance to the Gregorian calendar reform in France
}

Ed. note: This is a report on research conducted by the 2000 recipient of the Martinus Nijhoff International West European Specialist Study Grant, Jeffry Larson. ACRL will be accepting applications for the 2002 grant through May 1. For more information about the Martinus Nijhoff grant, visit http://www.ala.org/acrl/nijhoff.html.

Almost all that has been written on the revision of the Julian calendar in the 16 th century deals with the astronomical reasons for it or with the concomitant problems in dating events and documents. The calendar reform had seldom been studied in depth as an event in itself. In 2000, I received a Martinus Nijhoff International West European Specialist Study Grant to study the dissemination of the Gregorian calendar reform in France during the Wars of Religion.

Outside the papal states, the channels for disseminating the new calendar were from the Vatican via the papal nuncios to national sovereigns, who in turn, after ratifying it and having it printed, sent it on to the bishops in their countries. Thus, the chain was from ecclesiastical to secular then back to ecclesiastical authorities. In France, because of delays in printing and perhaps due to muted opposition in Parlement by Gallicans-partisans of national ecclesiastical autonomy - the reform was implemented only in December 1582, two months after Italy and Spain.

Coincidentally, with the granting of the Nijhoff award, there appeared a lengthy article by Jérôme Delatour in the Bibliotbèque de l'Ecole des Chartes based on collaborative archival research, largely in the Archives Nationales and the Bibliothèque Nationale, focusing just on this topic (my thanks to Bill Monroe of Brown University for the tip). Since such a large amount of the task had already been accomplished by others, I resolved to look for relevant materials where the team of researchers from the l'École des Chartes had not, namely among the unpublished letters of Henri III and Huguenot pamphlets in Parisian collections, and in diplomatic correspondence in the Secret Archives of the Vatican.

Henri III's letters are still in the process of being published; fair copies of them have been brought together in the Bibliothèque de l'Institut de France for the editorial project (in 2000, af- ter a gap of 16 years, the letters for 1580 to 1582 were published, but not extending into 1583). Scanning these documents, I discovered that calendar reform was not dealt with at the level of correspondence between sovereigns, which focused mostly on dynastic politics, foreign relations, and ecclesiastical appointments. The calendar was discussed, though not extensively, in the correspondence of the papal nuncio to France, whose letters have been published, with a few passages summarized. (I later checked the summaries against the originals in the Vatican Archives, but found nothing missing of import.)

Delatour had also analyzed the erudite Huguenot and Catholic treatises about the 1582 reform (which had led up to a bull in 1603 reaffirming the reform). So I looked for polemics at a more grass-roots level. Although the Bibliothèque de la Société de l'Histoire du Protestantisme Français was said by two research guides to have extensive pamphlet holdings, I found no such collections there. I shall extend my search to the Bibliothèque de l'Arsenal, repository of much ephemeral material, and the Bibliothèque Nationale de France.

Conflict over the calendar was isolated in time and space, and was reported not from Paris to the Vatican, but in the opposite direction. Delatour writes that a lawyer of Avignon ("un avocat d'Avignon") informed the Vatican of a priest being chased out of his parish in Courthezon, a town in southern Orange, for having published the new calendar. It was this incident that the Vatican asked its nuncio to bring to the attention of the French court. The correspondence from Avignon to the papal secretary revealed that the informant was in fact the Cardinal d'Armagnac (misread as "avocat"?), co-legate of Avignon and bishop of the diocese.

As representative of the Pope in Avignon, the Cardinal had implemented the new calendar at the same time in Italy and Spain. However, as the Cardinal clearly explains in his letter to the Vatican, the archdiocese was not coterminous with the papal state, but overlapped to include the parish of Courthezon in the principality of Orange, a hotbed of Protestant resistance. Evidently, the locals did not accept being ten days ahead of their compatriots and fellow market-goers in Orange, even if it was 
only for a few weeks and only in one parish. This clarification I plan to publish with appropriate documentation.

To identify the chronology of effective $\mathrm{Hu}-$ guenot acceptance of the Gregorian calendar, I now plan to look for ten-day gaps in congregational registers (baptisms, marriages, funerals), which are primarily in the Archives Nationales.

programs such as SPARC and SPARC Europe, which facilitate competition in scientific communication, and the establishment of institutional and discipline-based archives that allow public access to content and employ the Open Archives Metadata Harvesting Protocol.

\section{Fleet donates historic building to RISD library}

The Rhode Island School of Design (RISD) will receive a donation of space from FleetBoston Financial to house the school's new library. The donation of a portion of Fleet's facility includes the building's historic banking hall, second floor, and part of the basement. It will enlarge the capacity of RISD's library from 12,000 square feet to nearly 60,000 square feet.

The new library will provide for greater knowledge of the arts, design, and art eduction for the region and, through its location in downtown Providence, widen RISD's commitment to the Rhode Island public. The RISD Library opened in 1878 with its holdings in a single bookcase. Created as a specialized library of art and design publications and visual resources, the collection provides strong historical and contemporary perspectives and materials in landscape architecture, ceramics, textiles, sculpture, drawing, painting, Colonial furniture, and jewelry.

\section{Charles A. Schwartz named new PIL editor by ACRL board}

The ACRL Board of Directors has named Charles A. (Tony) Schwartz to be editor of ACRL's distinguished monographic series, Publications in Librarianship (PIL). Founded in 1953, the series focuses on research and theoretical discussion of issues in academic librarianship. The series has produced 54 titles since its inception.

Schwartz, who recently accepted the position of associate director for collection management at the Green Library at Florida Inter-
Much remains to be done, but I have unearthed a clarified account of the only recorded overt Huguenot resistance to the Gregorian calendar reform. I an very grateful to Martinus Nijhoff International and to my WESS colleagues for the opportunity to initiate this research.-Jeffry Larson, Yale University Library, jeffry.larson@yale.edu

national University, brings considerable publishing experience to the editorship. He has edited Restructuring Academic Libraries (number 49 in the PIL series), published numerous articles in ACRL's refereed scholarly journal College and Research Libraries, and served on the PIL editorial board. He will serve one year as an editor-designate apprentice with the current editor, John Budd, and begin his five-year term in July 2003.

\section{Pauling research notebooks released online}

Oregon State University (OSU) Special Collections has made available digitized versions of 46 research notebooks of two-time Nobel Laureate Linus Pauling. The Pauling Papers span from 1922 to 1994 and cover a range of the scientific fields in which Pauling was involved. The notebooks contain more than 7,500 pages and include many of Pauling's laboratory calculations and experimental data, scientific conclusions, ideas for further research, and autobiographical musings. The digitization, which was carried out by the OSU Special Collections staff, is available online at http:// osulibrary.orst.edu/specialcollections/mb/ index.html.

\section{ACRL publication focuses on libraries' impact on students}

Making the Grade: Academic Libraries and Student Success, edited by Maurie Caitlin Kelly and Andrea Kross, looks at the positive role that libraries play in student retention. The book presents useful analyses that consider the many factors that can impact student success, such

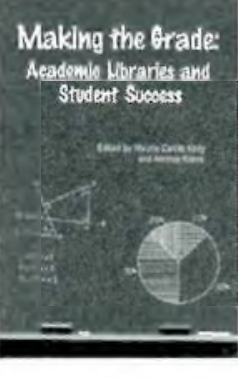
as technological capability, diversity, and information literacy.

The importance of libraries' partnerships 